РАЗВИЈАҢЕ ОТПОРНОСТИ НА СОЦИЈАЛНЕ ПРИТИСКЕ ВРШЫАКА

Весна Томић ${ }^{1}$

\title{
DEVELOPING RESISTANCE ON SOCIAL PRESSURE OF SAME AGE CHILDREN
}

Vesna Tomić

\section{Сажетак}

Третирање проблема сочијалног притиска вршњака од стране појединца или групе увод је у програмско здравственоваспитно деловање на унапређивању менталног здравља школске деце. $У$ условима нормализаџије насиља у друштву програмско деловање би било фокусирано на: ненасилну комуникацију ученика, развијање асертивности, проиес доношења одлука, изградюу сопствених капацитета и развијане толераниије $и$ недискриминативног понашањ а интерперсоналним односима.

Социјалне мреже као увод и финале насиља са бројним штетним последицама на психофизички развој младих део су интервентног програма који има за ииль учење за живот ученика кроз њихово оспособљавање запостављање питања, тражене одговора у проблемској ситуаиији, упознавање себе, упознавағе вредности мишљена - све заједно као одговора на соичјалне притиске вршьака.

Кључне речи: комуникачија, одлучивање, самоефикасност, ставови, асертивност.

\section{Summary}

Treating the problem of social pressure children of same age is introduction to programme of health education action on promoting mental health of school children. In the conditions of being normal of violence in the society programme intervention will be focused on: communication, making decisions, forming the personal capacities and developing tolerance and undiscrimination behavior in the interpersonal relations.

The aim of this intervention will be learning for life through making ability for: asking questions, making decision, knowing self. Forming values of thinking as active answer on social pressure.

Key words: communication, making decision, attitudes, self efficiency.

\footnotetext{
' Др сц. мед. Весна В. Томић, социјални психолог, Институт за јавно здравље Србије „Др Милан Јовановић Батут“, Београд, Србија.
} 


\section{УВОД У ПРОБЛЕМ}

$\mathrm{O}$ пшта конфузија изазвана стампедом дисперзије информација преко социјалних мрежа, медија, мобилних телефона, интернета, компјутера погодно је тле за ширење социјално неприхватљивих облика понашања.

Социјални притисци вршњака, као проблем педагошке праксе, имају део узрока настајања у насилној комуникацији младих. „Солидну“ основу за тај социјални феномен представља нормализација насилне комуникације у друштву која се реализује средствима масовних комуникација у свим сегментима популације код нас. Насилна комуникација је елемент групне динамике и иманентно садржи одраз моћи. Последице насилне комуникације су: губитак самопоштовања и самопоуздања ученика, слабији школски успех, промене у начину комуникације, психолошке последице могу да буду озбиљније ако се дуго трпи овакав вид комуникације кроз социјалне притиске појединца или групе.

Део проблема социјалних притисака вршњака односи се на покушаје негативног деловања у популацији младих на експериментисању са неким облицима понашања који могу да угрозе њихово здравље и тиме доведу до тренутних или трајних оштећења по здравље. Одређене уобичајене развојне карактеристике младих могу да олакшају такво социјално деловање што може да има за последицу њихову бржу интеграцију у социјални круг вршњака. Динамика функционисања групе захтева усвајање норми и стандарда понашања да би они били прихваћени у социјално референтном кругу као равноправни. Супротстављање томе може да буде санкционисано искључивањем појединца из групе вршњака или на други начин.

\section{КАРАКТЕРИСТИКЕ РАЗВОЈА УЧЕНИКА}

Емоционални развој ученика карактерише постепено повећање емоционалне стабилности. Општу карактеристику развоја представља осећање несигурности како за своју будућност тако и за будући социјални статус. Развојна емоција пред њих поставља дилему хоће ли бити прихваћени, толерисани, игнорисани или одбачени у свом непосредном социјалном окружењу. Несигурност је очигледна у њиховом изгледу и понашању.

Развој моралних схватања и ставова огледа се у све већој осетљивости према питањима сиромаштва, неправди, дискриминацији и другим негативностима савременог света. Савремене технологије, друштвене мреже и остала савремена помагала, колико олакшавају комуникацију између младих, толико умањују њен квалитет. Некада се јавља сукоб властитих моралних начела, што може имати за последицу осећање кривице или одбацивање начела која проглашавају застарелим.

Посебу опасност за ментално здравље, и опште здравствено стање младих представљају: улазак у секте, пробање и злоупотреба дувана, алкохола и наркотика.

Ученици имају потребе да развију: самопоуздање, припадност групи, самоуважавање, самосталност, способност да сами допринесу свом развоју, развију свесност и компетентност и блискост у бар неколико задовољавајућих интерперсоналних релација.

\section{ПЕРЦЕПЦИЈА, СОЦИЈАЛНА ПЕРЦЕПЦИЈА И СОЦИЈАЛНИ ПРИТИСАК}

Социјални ентитет (ученик, наставник, родитељ) је учесник у социјалној интеракцији уколико може да буде извор (субјект) или предмет (објект) социјалног деловања. Интеракцијски утицај ентитета огледа се у 
снази, ширини, домену његовог деловања на друге ентитете и њихове активности. Интерперсонална активност је основни облик социјалног понашања. Групна динамика је механизам психосоцијалне интеракције којим чланови групе утичу једни на друге.

Социјални амбијент (школа) ученици опажају дајући објектима опажања значење, што чини садржај перцепције која је сазнајни процес. Што је атипичност перцептивне ситуације већа, постоји склоност да се опажање прошири на увиђање - виђење ствари путем мишљења. Социјална перцепција је опажање интерперсоналних односа, а аутоперцепција опажање себе самоопажање. Социјална перцепција има неколико карактеристика: циљ социјалног понашања је особа и група, корелира са културним обрасцима средине и елемент је функционисања појединца у социјалном простору. У селекцији и дистрибуцији пажње најважнија је мотивација.

Као врста социјалних интеракција у склопу развијања отпорности на социјалне притиске вршњака издваја се комформирање. У педагошкој пракси то је један од начина деловања социјалног притиска на појединца. Као врста социјалног комфора комформирање одређују ставови или понашање на који норме, прописане улоге, стандарди и заједничко мишљење врше директиван и динамички утицај. Анализа комформирања дефинише се као прихватање понашања групе или већине зато што група такво понашање захтева, очекује и приказује га као социјално пожељно понашање. Комформирање је и онда када се не оцењује оправданост понашања већине, а оно се усваја без размишљања.

Код комформирања извор промене понашања је изазван притиском и без поговора, промену понашања изазива то што група очекује и захтева, а промене у понашању увек су у правцу групног понашања.

На комформирање утичу персонални и социјални фактори - први који потичу из структуре личности и њених диспозиција (узраст, пол, култура) и други који су из социјалне средине најшире схваћене (број чланова групе и статус онога ко врши притисак).

\section{РАЗВИЈАНЕ ОТПОРНОСТИ НА СОЦИЈАЛНЕ ПРИТИСКЕ}

Развијање отпорности на социјалне притиске је сложен когнитивни, вољни и емотивни процес који је у корелацији са формирањем ставова код ученика, почев од 11,12 . године па ка вишим узрастима. Ставови су трајно стечене диспозиције да се на доследан и конзистентан начин понаша према објекту, особи или ситуацији. Развијање ненасилне, ефикасне комуникације између субјеката у интеракцији подстаћи ће развој отпорности на социјалне притиске. У том контексту важно је водити рачуна о томе у којој мери је особа којој је порука намењена обратила пажњу на садржај поруке, да ли је схватила поруку, задржала поруку и реаговала као резултат поруке.

Неки аутори сматрају да код јачања отпорности на социјалне притиске кључно је постојање поверења у особу која врши притисак. Тај момент је значајан код омладине, јер они немају формиране јасне и чврсте ставове који су отпрони на промене. Једна од варијабли поруке је да ли рационално обраћање има ефикасније деловање од емоционалног. Када говоримо о школској популацији емоционално обраћање и вербално и невербално је од већег значаја. То се посебно односи на ситуације у којима се користе претња или застрашивање - интензивно је у форми одбацивања појединца из референтне групе којој припада.

Анализирајући персоналне диспозиције које смањују отпорност на социјалне притиске психолози наводе анксиозност и самопоштовање. Они тврде да постоји значајна корелација између хроничне анксио- 
зности, ниског самопоштовања, потребе за идентификацијом са групом вршњака и подложности утицају.

Препоруке за просветне раднике у циљу развијања отпорности ученика на социјалне притиске вршњака су:

1. Разговарајте са ученицима отворено и добронамерно.

2. Објасните им зашто је важно да мисле, пре него што донесу одлуку.

3. Подстичите их да говоре о одговорности за своје понашање и одлуке које су донели.

4. Објасните им улоге позитивних модела понашања - избегавајте негативне примере.

5. Објасните зашто је важан развој персоналних диспозиција, као што су самопоштовање, селф-концепт, сигурност.

6. Помозите им да препознају права и трајна пријатељства и њихову вредност за касније узрасте.

Процес доношења одлука је кључан у развијању отпорности на социјалне притиске повезујући формирање ставова и манифестованог понашања. Веза између ставова и понашања је таква да се на основу нечијих ставова не може предвидети понашање, али се на основу понашања може закључити о постојању ставова појединца у односу на објекте и ситуације.

У контексту развојних карактеристика адолесцената особености њиховог развоја које отежавају процес одлучивања су: несигурност, дихотомизирано мишљење, супротстављање ауторитету, комформирање, осећање омнипотенције. Особености које олакшавају овај процес су: широка интересовања, освајање позиција аутономног карактера, квантификација знања, контрола емоција, развијање тријаде: сазревање - учење - личне карактеристике.

Просветним радницима препоручујемо да подстакну развој следећег сета особина личности адолесцената: поштовање, одго- ворност, интелигенција, самосвест, самопоштовање, развијање позитивног животног стила, уважавање сопствених потреба и потреба других, унутрашња мотивација, унутрашњи локус контроле, самоефикасност, развој етичких принципа и стабилног система вредности.

\section{НЕНАСИЛНА КОМУНИКАЦИЈА И СОЦИЈАЛНИ ПРИТИСАК}

Социјална интеракција односи се на све врсте збивања или процеса који се одвијају унутар неке социјалне ситуације (школа) или између делова социјалног система који делују у оквирима заједничког социјалног простора. Актери у интеракцији су све врсте социјалних ентитета, како индивидуални (појединци) тако и мултииндивидуални (различите групе). Интерперсонална активност је основни облик социјалног понашања, а главни облик социјалних интеракција је комуникација - нема интеракције без комуникације.

Комуникација подразумева саопштавање и размену информација. Њен значај је у томе што је средство повезивања људи унутар различитих микросредина. Циљ комуникације у контексту социјалног притиска јесте придобијање појединца за неку акцију или понашање. За јачање отпорности на социјалне притиске значајна је подела на вербалну и невербалну комуникацију. Вербална комуникација најчешће почиње јасним убеђивањем циљаног субјекта (ученика), његовим подстицањем и охрабривањем да прихвати предложени модел понашања (нпр. пробање алкохола) и иде до његовог исмевања и омаловажавања уколико се предложено понашање не прихвати, а често се завршава и агресијом или искључивањем ученика из референтне групе вршњака.

Млади имају своју културу комуникације која подразумева висок степен јасноће у пријему и преради информација. Њен је циљ да малим бројем одабраних речи објасни 
суштину емитоване поруке у чему помажу основна начела ефикасне комуникације која се односе на предмет комуникације, на то коме је упућена и који се канали користе.

Да би информација која се шаље била ефикасна, треба да буде: јасна, целовита, тачна и правовремена. Наведена општа правила за обликовање јасне поруке у случају социјалног притиска су обрнути. Највећи ефекат на понашање ученика имаће она информација која је нејасна, непотпуна и нетачна и непозната.

C обзиром на чињеницу да у ситуацијама социјалног притиска често долази до конфликата између учесника у комуникацији, може се сматрати да је социјални притисак стресор за особу на коју се врши. Стресно деловање социјалног притиска вршњака може се идентификовати кроз:

1. Агресивно наметање туђег мишљења.

2. Подсмех и ругање ономе ко се одупире притиску.

3. Неслушање саговорника на кога се делује убеђивањем.

4. Елиминисање из социјално референтне групе.

5. Различите врсте психолошког малтретирања.

Ученици, као и одрасли, изложени су мноштву различитих информација и стимулуса који потичу из масовних медија, са друштвених мрежа, интернета и осталих савремених помагала. Истраживања о њиховом утицају на младе указују на доминацију теорија социјалног учења и њиховом деловању на понашање. Деца имитирају агресивна понашања (нетолеранцију, дискриминативност), посебно ако агресивни модели нису кажњавани. Информисање медија о “новим облицима забаве за младе" који су опасни и штетни по здравље њих провоцирају да са њима експериментишу, било да тако долазе у жижу јавности или задовољавају неке личне или социјалне потребе. Форме социјалног притиска један су од начина да се нездрави циљеви остваре у пракси.

Когнитивни развој деце има удела у начину на који млади доживљавају нове садржаје, али једнако важан је и њихов социјални углед и позиција коју освајају у референтној социјалној групи. Социјални притисак је погрешан начин како млади могу да задовоље део својих социјалних потреба и постану уважани у групи којој припадају. Испитивања у овој области указују да је важно контролисати факторе развоја као што су: иницијални ниво агресивности, динамика породичних односа, когнитивни стилови деце, степен идентификације са агресивним личностима из медија или друштвених мрежа, подложност утицајима савремених технологија.

Одговор на питање како комуницирати са ученицима на нивоу групе могуће је потражити у следећој шеми:

1. Планирање: комуникациони циљеви, шта се жели постићи, коме је намењена.

2. Организација: идеје и методе презентације.

3. Мотивација: нагласити корист за слушаоце.

4. Порука: циљати поруком на специфичну групу.

5. Закључак: поновити главне тачке поруке и користи.

6. Евалуација: провера резултата - питања и коментари.

На нивоу индивидуалне комуникације са ученицима издвојена су четири различита положаја особина личности на основу којих је могуће остварити ефикасну комуникацију:

- Оријентисаност према акцији - особе које воле акцију, достигнућа, решавање проблема, одлучни су и одговорни, брзи и енергични. У комуникацији са њима потребно је у центар пажње ставити резултате, формулисати најбоље 
препоруке, јасно и концизно и нагласити практичност идеја.

- Оријентисаност према процесу - воле чињенице, организовање, структурирање, анализирање, стрпљиви су и пажљиви. У комуникацији са таквом особом треба износити чињенице, разложити препоруке, укључити алтернативе за и против, не пожуривати такву особу.

- Оријентисаност према људима - негују интерперсоналне односе, односе пријатељства, солидарност, комуникативни су. Са њима треба инсистирати на персонализовању обраћања и комуникације, користити неформалан стил писања, испољити експлицитну подршку.

- Оријентисаност према идејама - усмеренисунаидеје,креативни,егоцентрични, провокативни, тешко их разумети. У комуникацији са њима треба издвојити доста времена за дискусију, отворено и јасно комуницирати, нагласити кључне премисе, приказати општу ситуацију, радити на специфичним задацима.

За ефикасну комуникацију потребно је примењивати рефлектовање садржаја и осећања које подразумева повратно исказивање делова садржаја или емоција који су делови комуникације да би истакли битне делове. Рефлектовање је потребно јер: обавезује саговорника да активно слуша, подстиче комуникацију и показује саговорнику да га други учесник слуша.

Рад на јачању отпорности на социјалне притиске вршњака реализује се индивидуалним и групним радом, и тражи додатну едукацију просветних радника у домену оспособљавања ученика за развој оних социјалних вештина које ће им помоћи у јачању.

\section{РАЗВОЈ САМОЕФИКАСНОСТИ У ЈАЧАНУ ОТПОРНОСТИ}

Многи облици понашања не могу да буду објашњени без појма самоефикасности која је у значајној повезаности са појмовима локуса контроле, оба заснована на когнитивним процесима и аутоперцепцији.

Локус контроле је опште уверење да особа може да контролише оно што јој се дешава. Особе са развијеним унутрашњим локусом контроле сматрају да могу да организују свој живот онако како они мисле да је исправно - имају пуно поверење у сопствене снаге и потенцијале. У случају неуспеха у реализацији неке активности они сматрају да су одговорни за такав исход. Особа са развијеним спољашњим локусом контроле, насупрот претходном типу, сматра да спољашњи фактори организују њихов живот и активности, па су они као такви одговорни и за њихов успех и неуспех.

Ефикасност је објективна способност особе да изведе одређено понашање. Мери се посматрањем да ли појединац реализује понашање или не. Перципирана самоефикасност је индивидуална процена способности да се одређено понашање изведе. Тако је ефикасност објективна мера извођења, а перципирана самоефикасност је процена појединца о његовој способности да изведе понашање. Коришћење појма самоефикасност увек подразумева перципирану самоефикасност. Тако дефинисана важна је карика између знања о томе шта треба чинити и актуелног чињења.

Самоефикасност утиче на:

1. Избор ситуација и понашања која ће особа да избегне или упражњава.

2. Напор који ће појединац да уложи у извођење понашања (више напора се улаже у она понашања која појединац опажа да ће бити успешно обављена).

3. Колико времена ће особа да проведе на извођењу понашања.

4. Јављање емоционалних реакција (нервоза, анксиозност, нераспложење). 
Знање о томе шта треба радити и уверење да неко може то да изведе нису једине детрминанте понашања. Поред знања, неопходне су и одређене вештине и способности као и мотиви за извођење понашања.

Самоефикасност се односи на специфичне бихевиоралне задатке. У том контексту не постоји општи осећај самоефикасности, већ он укључује самопоштовање и самопоуздање, оба у склопу односа према себи. Други важан аспект самоефикасности укључује способност предвиђања нечијег понашања.

На питање како људи уче да изводе специфична понашања, наводе се четири извора:

- Извођење онога што се желело постићи

- индивидуално понашање је најбољи индикатор способности извођења.

- Туђе искуство - социјалним поређењем и посматрањем онога што неко чини мислимо да смо и ми то у стању да изведемо.

- Вербално убеђивање - персуазија.

- Емоционално подстицање - самоефикасност може да буде под утицајем стресних и непланираних околности које подстичу настанак емоција које делују на перцепцију способности за извођење одређеног понашања.

Деловање самоефикасности на ментално здравље ученика огледа се кроз њихово оспособљавање за: доношење одлука, развој позитивне слике о себи, развој самоуважавања, развој вештина за решавање конфликата међу вршњацима.

За пружање отпора на социјалне притиске вршњака врло је важно како ученик себе процењује: да ли види да може да се одупре притиску или му је ефикасније да то не чини, већ да му подлегне. Један од начина да се то развије јесте указати им колико је важно самонаграђивање за одређене социјално прихватљиве облике понашања. Сви појмови о којима говоримо директно и индиректно доприносе формирању и јачању ставова код ученика, али оно што је важно за просветне раднике јесте правилно каналисати њихово формирање, јер су ставови врло отпорни на промене.

Самоуважавање (асертивност) је пожељни начин понашања у ситуацијама када треба решити неки потенцијални или манифестовани конфликт између субјеката у интеракцији. Развој асертивности један је од начина превенције стреса. У овом контексту налази место, јер се социјални притисак вршњака треба третирати као стресор за ученике у школској средини. Развој асертивности код ученика треба подстицати доводећи га у везу са самопоштовањем и позитивном сликом о себи. Обе наведене диспозиције високо корелирају са самоефикасношћу и јачањем отпорности на промену става.

\section{ЈАЧАЫЕ СОПСТВЕНИХ КАПАЦИТЕТА РАЗВОЈА И ОТПОРНОСТ НА СОЦИЈАЛНЕ ПРИТИСКЕ}

Општи је став да је свест о себи искуствена творевина која се развија током живота. Знање и свест о себи формирамо у оквиру актуелних, текућих социјалних односа. Доживљај себе не можемо одвојити од доживљаја средине која нас окружује и других особа са којима смо у интеракцији. Доказ за то је чињеница да људи успевају да сачувају свој идентитет, осећања, став и мишљење о себи упркос великим и очигледним променама средине или њиховог положаја у њој.

Људи усвајају и развијају когнитивне стратегије које им омогућавају да сачувају оно што осећају и мисле о себи, да своја знања о себи организују у кохерентну и смисаону целину. Те стратегије се заснивају на рационалном резоновању, иако се оно одвија у окружењу у коме доминирају емоције и потребе. Свака особа има о себи позитивно мишљење и та оцена прожима и 
обједињује све садржаје који чине њено знање о себи. Такође је познато да свака особа тражи доказе да су њене самооцене тачне.

Постоје три слике о себи:

1. Она коју смо сами конструисали.

2. Она коју други конструишу.

3. Она коју ми видимо у конструкцијама других.

У неким социјалним ситуацијама ученици немају сигурност да ће створити одређену импресију коју желе. Последице тога могу да буду:

- Несигурност како да то постигну, које поступке да одаберу и како да их изведу.

- Мишљење да нису способни да створе жељене реакције код других.

- Стварање жељене слике, али сматрају да она није довољно јака.

- Веровање да ће нешто догодити што ће угрозити њихово самоприказивање и довести их до тога да изгубе углед у референтној групи.

Анализа повезаности социјалне анксиозности код младих и самоприказивања показује да се социјална анксиозност појачава када особа жели или мора да остави одређени утисак на аудиторијум, а није сигурна да ће у томе успети. У таквој ситуацији особа предвиђа неповољне реакције других на своје понашање. У складу са теоријом социјалног учења претпоставља се да когнитивно стање особе посредује у артикулисању њеног афективног узбуђења и манифестованог понашања.

Од тренутка када се суочи са неким снажним стресором пред особом се налази неколико задатака које она треба да реши. Ти задаци су: интерпретација ситуације, конфронтирање са реалношћу, задржавање задовољавајуће слике о себи и одржавање социјалних веза. Социјални притисак вршњака увек је стресор за онога ко га трпи. Да ли је реално од младих очекивати да се адекватно припреме на животне до- гађаје који их ремете у уобичајеним бихевиоралним шемама?!

Одговор на ово питање је потврдан уколико се са њима обави одговарајућа превентивна психолошка припрема која се назива учење за живот, а заснована на две премисе:

- животне вештине је могуће научити;

- учење животним вештинама је процес у коме особа постоје способна да прихвати одговорност за себе и свој живот.

Учење животним вештинама је превентивни програм намењен ученицима, а реализује се методама драмских радионица, дискусионих група, анализом ситуације. Теоријску платформу овог приступа чине најшире схваћена хуманистичка одређења душевног здравља.

Основне вештине потребне за живот аутори овог приступа (Хопсон и Скали) деле у четири групе:

1. Вештине потребне за опстанак и развој - Како читати, како налазити информације, како конструктивно размишљати о проблемима и решавати их, како препознати креативни потенцијал у себи, како открити своја интересовања, како открити своја уверења и вредности, како поставити циљеве и остварити их, како имати позитивна осећања према себи, како превазилазити животне кризе, како мењати негативне емоције, како сачувати своје здравље, како урадити што више у садашњости.

2. Вештине потребне за комуницирање са другима - како подржавати друге, како утицати на људе, како сарађивати у групи, како конструктивно изражавати своја осећања, како успешно комуницирати, како успостављати, чувати и прекидати односе, како пружати и тражити помоћ.

3. Вештине потребне у заједници - како искористити могућности које заједница пружа.

4. Вештине потребне у специфичним ситуацијама - како изабрати животни стил, 
како учити, како изабрати занимање, како живети са другим људима, како провести слободно време.

Пред просветним и здравственим радницима је да припреме ученике у склопу развијања социјалне отпорности на суочавање са стресним ситуацијама, чиме ће ојачати њихови капацитети за развој. У том контексту је и развијање оптимистичког животног стила који код ученика подстиче развој самопоштовања и самопоуздања, а састоји се у: развијању унутрашњег локуса контроле, доживљавању стресора као изазова, тражење социјалне подршке, просоцијалној оријентацији, самосталном постављању циљева и одговорности за њих.

Најсигурнији начини за јачање отпорности на социјалне притиске вршњака су развој ефикасне комуникације и технике превладавања стреса које се односе на превладавање усмерено на:

- процес,

- проблем,

- емоције.

За ученике је нејефикасније савладавање усмерено на емоције са циљем да се постигне контрола сопствених емоција, препознавање истих код вршњака и њихово каналисање у социјално прихватљивом правцу.

\section{ЗАКЈУЧНО РАЗМАТРАЬЕ}

У друштву у коме свако четврто дете трпи неки облик агресије и насиља, а таблоиди и телевизијски програми пропагирају нормализацију насиља у друштву промивишући га у форми насилне комуникације (вербалне и физичке), пред просветним радницима су велики задаци и тешко решиви практични проблеми.

Јачањем отпорности на социјалне притиске вршњака појачао би се отпор према насиљу који је по својој природи комуникацијска вештина. Општа конфузија изазвана стампедом дисперзије информација преко социјалних мрежа, телефона, медија, као и губитак ауторитета институција довели су до гушења традиционалних вредности, анархије у вредносном систему и промовисања квазивредности.

С обзиром на то да је насиље групни феномен и одраз моћи, а насилници хетерогена група, младе је потребно оспособити да не трпе насиље (социјални притисак је један од облика насиља). Конфликти, често са озбиљним исходима, директна су последица социјалног притиска.

Напоре у здравственоваспитним интервенцијама (у којима социјални притисак обликује понашања ризична по здравље младих) треба усмерити на:

- јачање здравог колективитета,

- неузврћање насиљем, али га обавезно пријавити вршњаку или одраслом,

- изграђивање односа поверења са ученицима,

- формирање здравог начина живота, посебно улога спорта у томе - због формирања сета особина корисних за јачање отпора на социјалне притиске, као што су: самоконтрола, самодисциплина, самопоштовање, толеранција, пружање помоћи и подршке, сигурности у своје капацитете.

- претварање позитивних социјалних модела у узоре за своју референтну групу,

- ослобађање у комуникацији да саопште да су они или њихови другови жртве насиља.

Вршњачке групе, посебно адолесцентна група, је мала група коју чини 3 до 7 чланова узраста од 12 до 18 година, чији су чланови узајамно емотивно везани. Као малу групу карактерише их:

- непостојањепосебних групних задатака и циљева, али постојање заједничких активности;

- задовољење одређених потреба - персоналних и социјалних; 
- формирају се на основу узајамне привлачности чланова;

- не постоји формализована хијерархија вођства и моћи;

- изражено је комформирање нормама групе, а изражен је антикомформизам у односу на норме одраслих.

Норме адолесцентне групе обухватају различите области понашања: начин одношења према родитељима, наставницима и одраслим уопште, норме понашања према припадницима другог пола, према појединим друштвеним институцијама (школи) и неким друштвеним питањима.

У овако скицираном приказу друштвених односа и карактеристика адолесцентних група код ученика је могуће развијати и подстицати отпорност на социјалне притиске (индивидуалне и групне) једино континуираним здравственоваспитним програмским интерактивним деловањем просветних радника, здравствених радника, родитеља и ученика, све у склопу заштите и унапређивања њиховог менталног здравља.

\section{ЛИТЕРАТУРА}

1. Хавелка Н. Социјална перцепција. Завод за уџбенике и наставна средства, Београд, 1992.

2. Томић В. Процес доношења одлука адолесцената. Здравствена заштита, 2006; 5: 33-40.

3. Рот Н. Социјална интеракција II. Савез ДПС, Београд, 1980.

4. Kong SW. Communication and Social Infuence. Adison - Wesley, Massachussets, 1985.

5. Вучић Л. Развијање схватања социјалних односа код ученика. Завод за уџбенике и наставна средства, Београд, 1977.

6. Влајковић Ј. Животне кризе и њихово превазилажење. Нолит, Београд, 1992.

7. Радојевић М, Рајин Г, Лаловић М, Томић В. Индивидуално саветовање са адолесцентима у области заштите репродиктивног здравља. Центар за планирање породице Института за заштиту мајке и детета Србије, Импрес, Крагујевац, 2006.

8. Рот Н. Основи социјалне психологије. Завод за уџбенике и наставна средства, Београд, 1972.

Контакт: Др сц. мед. Весна В. Томић, социјални психолог, Институт за јавно здравље Србије „Др Милан Јовановић Батут“, Београд, Србија. 